\section{Mini-percoll gradient may be used for frozen-thawed sperm selection in sheep}

[Gradiente de mini-Percoll pode ser utilizado na seleção espermática de sêmen congelado de ovinos]

C.C.S. Olivares $^{1}$, J.M.G. Souza-Fabjan ${ }^{1,2}$, J.F. Fonseca ${ }^{3}$, H.F.R.A. Saraiva ${ }^{1}$, L.R. Côrtes ${ }^{1}$, V.A.P. Alfradique ${ }^{1}$, M.F.A. Balaro ${ }^{1}$, R.V. Oliveira ${ }^{4}$, F.Z. Brandão ${ }^{1}$

\author{
${ }^{1}$ Universidade Federal Fluminense - Niterói, RJ \\ ${ }^{2}$ Universidade do Grande Rio - Duque de Caxias, RJ \\ ${ }^{3}$ Embrapa Caprinos e Ovinos - Coronel Pacheco, MG \\ ${ }^{4}$ Universidade Federal Rural do Rio de Janeiro - Seropédica, RJ
}

C.C.S. Olivares1

https://orcid.org/0000-0001-6761-4419 J.M.G. Souza-Fabjan 1,2 h.M.G. Sorcid org/0000-0002-4872-1718 J.F. Fonseca3

https://orcid.org/0000-0001-8028-3984 H.F.R.A. Saraiva1

H.F.R.A. Saraiva1
https://orcid.org/0000-0003-4734-4794 L.R. Côrtes1

https://orcid.org/0000-0003-2731-0060 V.A.P. Alfradique 1 h.A.P. Alfradiquel M.F.A. Balaro1 M.F.A. Balarol
https://orcid org/0000-0002-8198-7964 https://orcid.org R.V. Oliveira4
https://orcid.org/0000-0002-7420-1097 h.t. Brandão1 https://orcid.org/0000-0003-4027-5562

\begin{abstract}
This study evaluated the effect of increasing centrifugalforce and reducing centrifugation time and volume in Percoll protocols on ram sperm parameters. Commercial semen of Santa Inês rams were used and five treatments were performed: traditional Percoll and mini-Percoll (MP) techniques (I- $5000 \times g$, $5 \mathrm{~min}$; II- $2500 \times \mathrm{g}$, 5min; III- $1250 \times \mathrm{g}$, 5min; IV- $700 \mathrm{x} \mathrm{g}, 10 \mathrm{~min}$ ). At post-thawing (PT) and postselection protocols (0h), samples were assessed for spermatozoa recovery rate, motility, plasma membrane (PM) integrity, sperm capacitation and morphology and incubated at $37 \mathrm{C}$ for 1,2 and $3 \mathrm{~h}$. The sperm recovery rate averaged $9.1 \pm 1.4 \%$, and most motility parameters were similar $(\mathrm{P}>0.05)$ among protocols. VCL $(\mu \mathrm{m} / \mathrm{s})$ was higher $(\mathrm{P}<0.05)$ after MP-II, III and IV $(66.1 \pm 4.5)$ than traditional Percoll (46.3 \pm 4.9). Capacitation status and PM integrity were similar ( $P>0.05)$ among treatments. For the first time, we have demonstrated the reduction of the gradient volume and centrifugation time associated with an increase on centrifugation force at Percoll can be successfully used for frozen-thawed ram sperm selection. MP may be used instead of traditional Percoll, decreasing costs and semen handling time.
\end{abstract}

Keywords:sperm capacitation, frozen-thawed sperm, ovine, percoll protocols

\title{
RESUMO
}

O presente estudo avaliou o efeito do aumento da força de centrifugação, bem como da redução do tempo de centrifugação e do volume do gradiente de Percoll em diferentes protocolos nos parâmetros espermáticos de ovinos. Foi utilizado sêmen comercial de carneiros da raça Santa Inês, e cinco tratamentos foram realizados: Percoll tradicional e quatro técnicas de mini-Percoll (I- $5000 \times$ g, 5min; II- $2500 \times \mathrm{g}$, 5min; III- $1250 \times \mathrm{g}$, 5min; IV- $700 \times \mathrm{g}$, 10min). Após o descongelamento e a seleção espermática em cada técnica utilizada (Oh), amostras foram avaliadas quanto à taxa de recuperação espermática, motilidade, integridade de membrana plasmática, capacitação e morfologia. Ao final, foram incubadas a $37^{\circ} \mathrm{C}$ por uma, duas e três horas. A taxa de recuperação média $(9,1 \pm 1,4 \%)$ e a maioria dos parâmetros de motilidade foram similares $(P>0,05)$ entre os tratamentos. VCL foi maior $(P<0,05)$ após MP-II, III e IV $(66,1 \pm 4,5)$ quando comparados ao Percoll tradicional $(46,3 \pm 4,9)$. $O$ status da capacitação e a integridade de membrana foram similares $(P>0,05)$ entre os tratamentos. Pela primeira vez, foi demonstrado que a redução do volume do gradiente utilizado e do tempo de centrifugação, associada com o aumento da força de centrifugação nos protocolos de Percoll, pode ser usada com sucesso na seleção espermática de sêmen congelado de ovinos. O mini-Percoll pode ser utilizado em alternativa à técnica de Percoll tradicional, diminuindo custos e tempo de manipulação do sêmen durante a técnica.

Palavras-chave: capacitação espermática, sêmen congelado, ovino, protocolos de Percoll 


\section{INTRODUCTION}

The success of in vitro fertilization (IVF) and subsequent development during in vitro production of embryos (IVP) are directly related to oocyte quality and maturation, the selection of good quality spermatozoa. With the advent of biotechnology applied to assisted reproduction, there was a need to develop strategies for rigorous sperm preparation since, in most cases, cryopreserved cells are required (Souza-Fabjan et al., 2014).

In order to achieve a sperm preparation based on natural principles, sperm selection events are mimicked to the success of IVP. Therefore, it is very important to develop high-quality procedures, providing a normal and healthy selection. The sperm selection methods used in sheep are: swim-up (Shirazi and Motaghi, 2013; Luna et al., 2015), Percoll density gradients (Wang et al., 2013; García-Álvarez et al., 2015) and sperm washing by centrifugation (Cocero et al., 2011; Mara et al., 2013).

Studies commonly describe a 2mL-Percoll gradient centrifugation technique, prepared at $700 \times \mathrm{g}$ for a period of 10-20 minutes (Machado et al., 2009; García-Álvarez et al., 2015). However, the search for a maximum recovery of good quality sperm, led to several changes over the years in this technique. Possibly, the main change was a decrease in the volume of the density gradient, using a higher centrifugation force and shorter time of procedure, characterizing the mini-Percoll (MP) protocols. In cattle (Machado et al., 2009) and goat (Olivares et al., 2015) species, it was demonstrated that the mini-Percoll technique could be applied for sperm selection. Machado et al. (2009) reported that decreasing Percoll volume, reducing the duration of centrifugation, and using a higher centrifugation force had no adversely effect on bovine sperm quality and embryo development. Moreover, the authors obtained higher cleavage and blastocysts rates for mini-Percoll when compared to traditional Percoll.

The use of MP technique appears as an attractive alternative to minimize the cost, reduce the contact with the density gradient molecules that cause toxicity in humans (Strehler et al., 1998) and, thus, to decrease sample processing time during IVP (Machado et al., 2009). However, the number of studies about the effect of MP techniques in small ruminants (Pegoraro et al., 2013; Olivares et al., 2015) is still very limited in comparison with bovine. As such, the aims of this study were to compare the effectiveness and influence of four different MP techniques with the traditional Percoll in several parameters of Santa Inês ram frozen-thawed sperm.

\section{MATERIALS AND METHODS}

The procedures were approved by the local ethic committee (protocol approval: 374/13). All chemicals used were from Sigma Chemical (St. Louis, USA). Exceptions were acridine orange and propidium iodide obtained from Halotech DNA (Madrid, Spain).

Commercial frozen semen straws $(0.25 \mathrm{~mL}$; initial concentration: $226.7 \pm 15.9 \times 10^{6} \mathrm{sptz} / \mathrm{mL}$ ) of the same batch from 10 Santa Inês rams aging $2-5$ years old, sexually matured and of proved fertility were used. The straws were thawed at $37^{\circ} \mathrm{C}$ for $30 \mathrm{~s}$. A pool of five straws of the same ram was thawed and homogenized in a warmed $1.5 \mathrm{~mL}$ microtube (Eppendorf Brasil, São Paulo, Brazil). At post-thawing (PT), we evaluated sperm concentration, motility, plasma membrane (PM) integrity and morphology. The semen was divided and submitted to either: traditional Percoll or four different MP techniques for sperm selection. Similarly, at the end of all treatments (post-selection protocols $=0 \mathrm{~h}$ ) sperm recovery, motility, PM integrity, sperm capacitation and morphology were accessed. Afterwards, samples of all treatments were submitted to incubation at $37^{\circ} \mathrm{C}$, for $1 \mathrm{~h}, 2 \mathrm{~h}$, and $3 \mathrm{~h}$ and the same parameters mentioned were assessed among the intervals, except the recovery rate.

The sperm selection by Percoll technique was established based on the method by Papadopoulos et al. (2005), with slight modifications. A total of $2 \mathrm{~mL}$-gradient $(90 / 45 \%$ density) of Percoll solution was prepared and a $0.15 \mathrm{~mL}$ aliquot of semen was poured into the Percoll gradient tube and it was subjected to a $700 \times g$ centrifugation for $10 \mathrm{~min}$. At the end of centrifugation, the supernatant was removed and the sample was again subjected to another centrifugation in SP-TALP (supplemented with $3 \mathrm{mg} / \mathrm{mL}$ BSA V, $2.2 \mathrm{mg} / \mathrm{mL}$ sodium pyruvate, 
$50,000 \mathrm{UI} / \mathrm{mL}$ penicillin and $50 \mathrm{mg} / \mathrm{mL}$ streptomycin), at $200 \times g$ for $5 \mathrm{~min}$. After the second centrifugation, the pellet was resuspended in $0.4 \mathrm{~mL}$ of SP-TALP.

The mini-Percoll protocols were performed: (i) mini-Percoll I (MP-I): two centrifugations of $5000 \times \mathrm{g}$ for 5min (Machado et al., 2009); (ii) mini-Percoll II (MP-II): two centrifugations of $2500 \times \mathrm{g}$ for 5min; (iii) mini-Percoll III (MP-III): two centrifugations of $1250 \times \mathrm{g}$ for $5 \mathrm{~min}$; (iv) mini-Percoll IV (MP-IV): $700 \times \mathrm{x} g$ for $10 \mathrm{~min}$ (following the same force and time of centrifugation of the traditional Percoll technique), followed by another centrifugation in SP-TALP, at $200 \times \mathrm{g}$ for $5 \mathrm{~min}$. For all protocols, the gradient was formed by pipetting $0.4 \mathrm{~mL}$ of $90 \%$ Percoll and then overlaying it with $0.4 \mathrm{~mL}$ of $45 \%$ Percoll solution. A $0.15 \mathrm{~mL}$ aliquot of semen was placed onto the top of the $45 \%$ layer and then centrifuged. After the second centrifugation, the pellet was resuspended in $0.4 \mathrm{~mL}$ of SP-TALP.

The sperm concentration rate was obtained after each treatment by using a Neubauer counting chamber after spermatozoa dilution (1:200). The rate was calculated by the formula: (final concentration $\times$ final volume) $\times$ (initial concentration $\times$ initial volume $)^{-1} \times 100$. The morphology evaluation was carried out by the preparation of wet smears previously diluted in formol saline solution. Using 1000x magnification with oil immersion under phase contrast microscopy, sperm cells were evaluated to establish the percentage of sperm cells with normal morphology (Bloom, 1973). The capacitation status was assessed by chlortetracycline (CTC) test and was based at the technique described by Pérez-Pé et al. (2002), with slight modifications. A $0.75 \mathrm{mM}$ CTC solution was daily prepared in a buffer containing $20 \mathrm{mM}$ Tris, $130 \mathrm{mM} \mathrm{NaCl}$ and $5 \mathrm{Mm}$ cysteine, $\mathrm{pH} 7.8$. For staining, $0.01 \mathrm{~mL}$ of sperm sample were mixed with $0.01 \mathrm{~mL}$ of CTC solution onto a glass slide. Finally, a drop of an antifade solution (0.22M 1,4-diazabicyclo [2.2.2] octane, DABCO) was mixed to retard the fading of CTC fluorescence. The samples were observed in a microscope (Nikon Eclipse Ci, Nikon Corporation, Tokyo, Japan) under epifluorescence illumination, in 1000x magnification with oil immersion. One hundred spermatozoa per slide were scored (Chamberland et al., 2001) and classified as described by Cormier et al. (1997): bright fluorescence over the whole head (noncapacitated cells, F pattern); fluorescence-free band in the postacrosomal region (capacitated cells, B pattern); and full fluorescence over the whole head except for a thin, bright band of fluorescence along the equatorial region (acrosome-reacted cells, AR pattern; Figure 1).
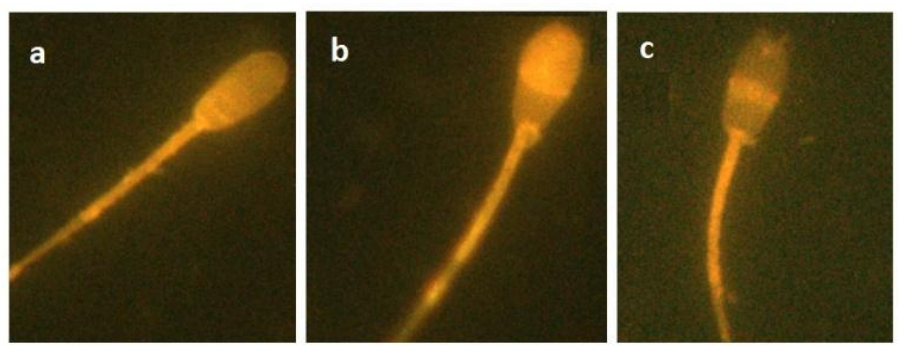

Figure 1. CTC patterns of ram frozen-thawed spermatozoa, under epifluorescence illumination at 1000x. (a) F pattern (noncapacitated cells); (b) B pattern (capacitated cells); (c) AR pattern (acrosome-reacted cells).

Sperm motility parameters were analyzed by computer-assisted semen analysis (CASA) using the $\mathrm{SCA}^{\circledR}$ system (Sperm Class Analyzer Microptic, Automatic Diagnostic Systems Barcelona, Spain) connected to a microscope and the following settings were applied: image collection speed: 25 images per second; magnifying power of microscope: x 100; measurements were performed in a 24 x $24 \mathrm{~mm}$ coverslide with a $10 \mu \mathrm{L}$ sample drop volume. Sperm movement was observed under negative phase contrast optics and videotape recorded in three diferent fields, at least. Software settings were adjusted to ram spermatozoa. The main software settings were as follows: the sperm head dimensions detected by the system were 
between 18 and $60 \mu \mathrm{m}^{2}$. Spermatozoa were identified as immotile by curvilinear velocity (VCL) below $10 \mu \mathrm{m} / \mathrm{s}$; between 10 and $45 \mu \mathrm{m} / \mathrm{s}$ were classified as slow; between 45 and $75 \mu \mathrm{m} / \mathrm{s}$ were classified as medium; and above $75 \mu \mathrm{m} / \mathrm{s}$ were classified as rapid. The sperm cells presenting straightness (STR) above $80 \%$ were featured as progressive. The following motility patterns were analyzed: total motility (\%), progressive motility (\%), fast sperm (\%), average path velocity (VAP; $\mathrm{mm} / \mathrm{s}), \mathrm{VCL}(\mathrm{mm} / \mathrm{s})$, straight line velocity (VSL; mm/s), straightness (STR: VSL/VAP; \%), linearity (LIN: VSL/ VCL; \%), wobble (WOB: VAP/ VCL; \%), lateral head displacement $(\mathrm{ALH} ; \mathrm{mm})$ and beat cross frequency $(\mathrm{BCF} ; \mathrm{Hz})$.

The PM integrity was carried out by VitalTest kit, based on acridine orange and propidium iodide labelling and followed manufacturer instructions. At least 100 spermatozoa per slide were analyzed. An epifluorescence microscope was used, at 100x magnification. This procedure resulted in selective labelling of either damage or normal cells visualized in red or green colors, respectively.

Statistical analyses were performed using the 9.0 $\mathrm{SAEG}^{\circledR}$ program. For all data, the treatment effect (GI, GII, GIII and GIV), incubation time effect (1, 2 and $3 \mathrm{~h})$ and the interaction among treatments and incubation time (both independent variables) on the response variables (dependent ones) were assessed. Quantitative variables (motility, viability, sperm recovery rate, capacitation and morphology) were subjected to normality (Lilliefors test) and homoscedasticity tests and two-way analysis of variance (ANOVA) was performed with Tukey or Fisher-LSD tests for means comparisons. A value of $\mathrm{P}<0.05$ was considered as statistically significant.

\section{RESULTS}

The final sperm concentrations did not vary $(\mathrm{P}>$ 0.05) after the sperm selection techniques (Percoll: 15.1 \pm 1.9 ; MP-I: 23.2 \pm 3.2 ; MP-II: 19.6 \pm 2.6 ; MP-III: $21.9 \pm 3.5$; MP-IV: $23.5 \pm 3.1 \mathrm{x}$ $\left.10^{6} \mathrm{sptz} / \mathrm{mL}\right)$, resulting in a similar $(\mathrm{P}>0.05)$ sperm recovery rate between traditional Percoll and any MP treatment (Percoll: $6.5 \pm 1.5$; MP-I: 10.8 \pm 1.7 ; MP-II: $8.8 \pm 1.4$; MP-III: $9.3 \pm 1.0$; MPIV: $10.1 \pm 1.2 \%)$. The majority of sperm parameters assessed were not affected $(\mathrm{P}>0.05)$ by the selection technique motility at $0 \mathrm{~h}$, as listed in Table 1. The only exception was VCL parameter that was higher $(\mathrm{P}<0.05)$ after the MP techniques II, III and IV when compared to traditional Percoll (Table 1). Regardless to the treatment, high rates of acrosome-reacted and capacitated cells were verified in the current study and it they were not different among the treatments. The proportion of sperm with PM integrity and morphological defects did not differ among treatment groups $(\mathrm{P}>0.05)$.

Table 1. Sperm motility values immediately after spermatozoa selection by different treatments in ram frozen-thawed sperm of Santa Inês breed (mean \pm SEM)

\begin{tabular}{|c|c|c|c|c|c|c|c|c|c|c|c|}
\hline $\begin{array}{l}\text { Treatment/ } \\
\text { Parameter }\end{array}$ & $\begin{array}{c}\text { Total } \\
\text { motility } \\
(\%)\end{array}$ & $\begin{array}{c}\text { Progressive } \\
\text { sperm } \\
(\%)\end{array}$ & $\begin{array}{c}\text { Fast } \\
\text { sperm } \\
(\%) \\
\end{array}$ & $\begin{array}{c}\mathrm{VCL} \\
(\mu \mathrm{m} / \mathrm{s})\end{array}$ & $\begin{array}{c}\text { VSL } \\
(\mu \mathrm{m} / \mathrm{s})\end{array}$ & $\begin{array}{c}\text { VAP } \\
(\mu \mathrm{m} / \mathrm{s})\end{array}$ & $\begin{array}{l}\text { ALH } \\
(\mu \mathrm{m})\end{array}$ & $\begin{array}{l}\text { BCF } \\
(\mathrm{Hz})\end{array}$ & $\begin{array}{l}\mathrm{LIN} \\
(\%)\end{array}$ & $\begin{array}{l}\text { STR } \\
(\%)\end{array}$ & $\begin{array}{c}\text { WOB } \\
(\%)\end{array}$ \\
\hline Percoll & $\begin{array}{c}32.4 \pm \\
3.6\end{array}$ & $\begin{array}{c}8.2 \pm \\
1.7\end{array}$ & $\begin{array}{c}7.8 \pm \\
1.4\end{array}$ & $\begin{array}{c}46.3 \pm \\
4.9^{b}\end{array}$ & $\begin{array}{c}33.8 \pm \\
4.8\end{array}$ & $\begin{array}{c}38.6 \pm \\
5.0\end{array}$ & $\begin{array}{c}1.3 \pm \\
0.2\end{array}$ & $\begin{array}{c}6.1 \pm \\
0.8\end{array}$ & $\begin{array}{c}69.1 \pm \\
5.2\end{array}$ & $\begin{array}{c}84.8 \pm \\
3.3\end{array}$ & $\begin{array}{c}80.3 \pm \\
4.0\end{array}$ \\
\hline $\begin{array}{l}\text { mini- } \\
\text { Percoll I }\end{array}$ & $\begin{array}{c}35.2 \pm \\
5.6\end{array}$ & $\begin{array}{c}10.5 \pm \\
1.9\end{array}$ & $\begin{array}{c}10.4 \pm \\
1.8\end{array}$ & $\begin{array}{l}58.5 \pm \\
3.6^{\mathrm{a}, \mathrm{b}}\end{array}$ & $\begin{array}{c}42.7 \pm \\
4.6 \\
\end{array}$ & $\begin{array}{c}48.9 \pm \\
4.5 \\
\end{array}$ & $\begin{array}{c}1.8 \pm \\
0.2 \\
\end{array}$ & $\begin{array}{c}7.3 \pm \\
0.3 \\
\end{array}$ & $\begin{array}{c}71.7 \pm \\
3.7 \\
\end{array}$ & $\begin{array}{c}86.3 \pm \\
2.1 \\
\end{array}$ & $\begin{array}{c}82.6 \pm \\
2.7\end{array}$ \\
\hline $\begin{array}{l}\text { mini- } \\
\text { Percoll III }\end{array}$ & $\begin{array}{c}45.7 \pm \\
6.8 \\
\end{array}$ & $\begin{array}{c}17.1 \pm \\
3.7 \\
\end{array}$ & $\begin{array}{c}17.4 \pm \\
3.9 \\
\end{array}$ & $\begin{array}{c}66.2 \pm \\
5.5^{\mathrm{a}} \\
\end{array}$ & $\begin{array}{c}49.4 \pm \\
5.3 \\
\end{array}$ & $\begin{array}{c}57.3 \pm \\
5.5 \\
\end{array}$ & $\begin{array}{c}1.8 \pm \\
0.1 \\
\end{array}$ & $\begin{array}{c}6.9 \pm \\
0.2 \\
\end{array}$ & $\begin{array}{c}73.5 \pm \\
3.4\end{array}$ & $\begin{array}{c}85.5 \pm \\
2.1 \\
\end{array}$ & $\begin{array}{c}85.6 \pm \\
2.3 \\
\end{array}$ \\
\hline $\begin{array}{l}\text { mini- } \\
\text { Percoll IV }\end{array}$ & $\begin{array}{c}45.6 \pm \\
5.7\end{array}$ & $\begin{array}{c}18.1 \pm \\
3.5\end{array}$ & $\begin{array}{c}18.5 \pm \\
4.3\end{array}$ & $\begin{array}{c}67.4 \pm \\
5.2^{\mathrm{a}} \\
\end{array}$ & $\begin{array}{c}52.6 \pm \\
5.0\end{array}$ & $\begin{array}{c}59.7 \pm \\
5.5\end{array}$ & $\begin{array}{c}1.7 \pm \\
0.1\end{array}$ & $\begin{array}{c}6.9 \pm \\
0.2\end{array}$ & $\begin{array}{c}77.2 \pm \\
2.5\end{array}$ & $\begin{array}{c}87.8 \pm \\
1.3\end{array}$ & $\begin{array}{c}87.8 \pm \\
1.7\end{array}$ \\
\hline Mean & $\begin{array}{c}40.8 \pm \\
5.7\end{array}$ & $\begin{array}{c}14.3 \pm \\
3.1\end{array}$ & $\begin{array}{c}14.4 \pm \\
3.4\end{array}$ & $\begin{array}{c}60.6 \pm \\
5.5\end{array}$ & $\begin{array}{c}45.2 \pm \\
5.3\end{array}$ & $\begin{array}{c}51.9 \pm \\
5.7\end{array}$ & $\begin{array}{c}1.7 \pm \\
0.2\end{array}$ & $\begin{array}{c}6.8 \pm \\
0.4\end{array}$ & $\begin{array}{c}72.6 \pm \\
3.7\end{array}$ & $\begin{array}{c}85.9 \pm \\
2.1\end{array}$ & $\begin{array}{c}83.9 \pm \\
2.8\end{array}$ \\
\hline
\end{tabular}

Within a column, values without a common superscript $\left({ }^{\mathrm{a}, \mathrm{b}}\right)$ differ significantly by Tukey test $(\mathrm{P}<0.05)$; $\mathrm{n}=10$; Percoll: $700 \times \mathrm{g}$ for $10 \mathrm{~min}$ followed by $200 \times \mathrm{g}$ for $5 \mathrm{~min}$; mini-Percoll I: $5000 \times \mathrm{x}$ for $5 \mathrm{~min}$ twice; mini-Percoll II: $2500 \times \mathrm{g}$ for $5 \mathrm{~min}$ twice; mini-Percoll III: $1250 \mathrm{x} g$ for $5 \mathrm{~min}$ twice; mini-Percoll IV: $700 \mathrm{x} g$ for $10 \mathrm{~min}$ followed by 200 x $g$ for 5min; VCL: curvilinear velocity; VSL: straight line velocity; VAP: average path velocity; ALH: lateral head displacement; BCF: beat cross frequency; LIN: linearity; STR: straightness;WOB:wobble. 
There was no interaction between incubation interval and treatments for all variables studied. However, when we pool the data regardless of the interval of incubation (average from 0 to $3 \mathrm{~h}$ ), there was no difference (P>0.05) among the treatments for total motility, progressive sperm, fast sperm and slow sperm (Figure 2). Similarly, no differences $(\mathrm{P}>0.05)$ were found for all the other motility parameters, such as VCL, VSL, VAP, ALH, BCF, LIN, STR and WOB (data not shown). There was no difference ( $\mathrm{P}>0.05$ ) among the treatments when the intervals of incubation were compared, for all motility parameters described.

When we pool the data regardless of the treatment, considering only the moment of evaluation (average of all treatments), there were significant differences in motility parameters, as shown in Table 2. The rate of motility, progressive sperm and fast sperm, was higher $(\mathrm{P}<0.05)$ in PT compared to other moments. These parameters were also higher $(\mathrm{P}<0.05)$ immediately after the protocols $(0 \mathrm{~h})$ in relation to any incubation interval. After $1 \mathrm{~h}$ of incubation, these parameters decreased $(\mathrm{P}<0.05)$ dramatically. As expected, the slow sperm rate was higher $(\mathrm{P}<0.05)$ at all incubation intervals than at PT (data not shown). For VCL, VSL, VAP and ALH, the PT values were higher $(\mathrm{P}<$
$0.05)$ than all other moments. For all variables, Oh was higher $(\mathrm{P}<0.05)$ then all incubation intervals. After evaluating VCL, VSL, VAP, LIN, STR and ALH there was no difference (P> 0.05 ) between the intervals of $1 \mathrm{~h}$ and $2 \mathrm{~h}$ and between $2 \mathrm{~h}$ and $3 \mathrm{~h}$, but the values were higher $(\mathrm{P}<0.05)$ at $1 \mathrm{~h}$ in comparison with $3 \mathrm{~h}$. For WOB and $\mathrm{BCF}$, values were higher $(\mathrm{P}<0.05)$ at $1 \mathrm{~h}$ when compared to $2 \mathrm{~h}$ or $3 \mathrm{~h}$ of incubation.

There was no difference $(\mathrm{P}>0.05)$ among the treatments when the intervals of incubation were compared, for capacitation status and PM integrity. However, overall, when we pool the data regardless of the interval of incubation (average from 0 to $3 \mathrm{~h}$ ), there was no difference (P> 0.05) for Percoll, MP-I, MP-II, MP-III and MP-IV, for: capacitated $(24.0 \pm 2.2,25.4 \pm 1.7$, $24.4 \pm 1.6, \quad 27.5 \pm 2.0 \quad$ and $26.6 \pm 2.2 \%$, noncapacitated $\quad(5.1 \pm 0.9, \quad 3.6 \pm 1.0, \quad 4.4 \pm 0.9$, $4.1 \pm 0.9$ and $3.2 \pm 0.6 \%$, acrosome-reacted $(70.8 \pm 2.5, \quad 71.0 \pm 1.9, \quad 71.2 \pm 2.0, \quad 68.4 \pm 1.9$ and $70.3 \pm 2.2 \%)$, major $(2.8 \pm 1.9,2.8 \pm 1.6,2.5 \pm 2.0$, $3.6 \pm 4.4$ and $3.8 \pm 5.5 \%$ ) and minor $(7.4 \pm 6.2$, $9.1 \pm 5.9,8.3 \pm 5.9,8.4 \pm 6.1$ and $8.4 \pm 5.4 \%$ ) defects. Similarly, no differences $(\mathrm{P}>0.05)$ were found regarding PM integrity for either intact $(9.0 \pm 1.8$, $10.0 \pm 1.5,12.0 \pm 2.1,11.0 \pm 2.2$ and $13.0 \pm 2.6 \%$ ) or damaged $\quad(91.0 \pm 1.8, \quad 90.0 \pm 1.5, \quad 88.0 \pm 2.1$, $89.0 \pm 2.2$ and $86.0 \pm 2.6 \%$ ) cells.



Figure 2. Motility parameters after different treatments in ram frozen-thawed sperm of Santa Inês breed (P< 0.05). MP-I: mini-Percoll I; MP-II: mini-Percoll II; MP-III: mini-Percoll III; MP-IV: mini-Percoll IV. 
Table 2.Sperm motility values after different assay moments of Percoll protocols in ram frozen-thawed sperm of Santa Inês breed (Mean \pm SEM)

\begin{tabular}{|c|c|c|c|c|c|c|c|c|c|c|c|}
\hline $\begin{array}{l}\text { Moment/ } \\
\text { Parameter }\end{array}$ & $\begin{array}{c}\text { Total } \\
\text { motility } \\
(\%)\end{array}$ & $\begin{array}{c}\text { Progressive } \\
\text { sperm }(\%)\end{array}$ & $\begin{array}{c}\text { Fast } \\
\text { sperm } \\
(\%) \\
\end{array}$ & $\begin{array}{c}\text { VCL } \\
(\mu \mathrm{m} / \mathrm{s})\end{array}$ & $\begin{array}{c}\text { VSL } \\
(\mu \mathrm{m} / \mathrm{s})\end{array}$ & $\begin{array}{l}\text { VAP } \\
(\mu \mathrm{m} / \mathrm{s})\end{array}$ & $\begin{array}{l}\text { ALH } \\
(\mu \mathrm{m})\end{array}$ & $\begin{array}{l}\mathrm{BCF} \\
(\mathrm{Hz})\end{array}$ & $\begin{array}{l}\text { LIN } \\
(\%)\end{array}$ & $\begin{array}{l}\text { STR } \\
(\%)\end{array}$ & $\begin{array}{c}\text { WOB } \\
(\%)\end{array}$ \\
\hline $\mathrm{PT}^{*}$ & $52.3 \pm$ & $19.7 \pm$ & $22.0 \pm$ & $73.1 \pm$ & $53.2 \pm$ & $62.0 \pm$ & $2.5 \pm$ & $7.8 \pm$ & $71.0 \pm$ & $84.5 \pm$ & $83.5 \pm$ \\
\hline \multirow[b]{2}{*}{ Oh } & $41.0 \pm$ & $14.3 \pm$ & $14.4 \pm$ & $60.6 \pm$ & $45.2 \pm$ & $51.9 \pm$ & $1.7 \pm$ & $6.8 \pm$ & $72.6 \pm$ & $86.0 \pm$ & $83.9 \pm$ \\
\hline & $2.5^{\mathrm{b}}$ & $1.6^{\mathrm{b}}$ & $1.5^{\mathrm{b}}$ & $2.4^{\mathrm{b}}$ & $2.4^{\mathrm{b}}$ & $2.5^{\mathrm{b}}$ & $0.07^{\mathrm{b}}$ & $0.2^{\mathrm{a}}$ & $1.7^{\mathrm{a}}$ & $0.9^{\mathrm{a}}$ & $1.3^{\mathrm{a}}$ \\
\hline \multirow{2}{*}{$2 \mathrm{~h}$} & $22.0 \pm$ & $1.6 \pm$ & $1.5 \pm$ & $22.5 \pm$ & $10.4 \pm$ & $13.7 \pm$ & $0.7 \pm$ & $2.7 \pm$ & $39.7 \pm$ & $66.0 \pm$ & $55.1 \pm$ \\
\hline & $1.6^{\mathrm{c}}$ & $0.9^{\mathrm{c}}$ & $0.3^{\mathrm{c}}$ & $1.3^{\mathrm{c}, \mathrm{d}}$ & $1.4^{\mathrm{c}, \mathrm{d}}$ & $1.4^{\mathrm{c}, \mathrm{d}}$ & $0.1^{\mathrm{c}, \mathrm{d}}$ & $0.4^{\mathrm{c}}$ & $3.2^{\mathrm{b}, \mathrm{c}}$ & $2.8^{\mathrm{b}, \mathrm{c}}$ & $2.9^{c}$ \\
\hline \multirow{2}{*}{$3 \mathrm{~h}$} & $24.0 \pm$ & $1.1 \pm$ & $0.8 \pm$ & $18.5 \pm$ & $7.3 \pm$ & $10.1 \pm$ & $0.5 \pm$ & $2.3 \pm$ & $34.7 \pm$ & \multirow{2}{*}{$62.3 \pm 2.3^{c}$} & $49.9 \pm$ \\
\hline & $2.1^{\mathrm{c}}$ & $0.8^{\mathrm{c}}$ & $0.2^{\mathrm{c}}$ & $0.7^{\mathrm{d}}$ & $0.8^{\mathrm{d}}$ & $0.9^{\mathrm{d}}$ & $0.1^{\mathrm{d}}$ & $0.4^{\mathrm{c}}$ & $3.1^{\mathrm{c}}$ & & $3.0^{\mathrm{c}}$ \\
\hline Mean & $32.0 \pm$ & $8.0 \pm$ & $8.3 \pm$ & $40.6 \pm$ & $26.3 \pm$ & $31.4 \pm$ & $1.3 \pm$ & $4.8 \pm$ & $53.5 \pm$ & $74.5 \pm$ & $67.3 \pm$ \\
\hline
\end{tabular}

Within a column, values without a common superscript $\left({ }^{\mathrm{a}, \mathrm{b}, \mathrm{c}, \mathrm{d}}\right)$ differ significantly by Tukey test $(\mathrm{P}<0.05) ; \mathrm{n}=50$ (ten replicates for each treatment); *PT: Post thawing; 0h: immediately after treatments; $1 \mathrm{~h}, 2 \mathrm{~h}$ and $3 \mathrm{~h}$ : hours of incubation after each selection technique; VCL: curvilinear velocity; VSL: straight line velocity; VAP: average path velocity; ALH: lateral head displacement; BCF: beat cross frequency; LIN: linearity; STR: straightness; WOB: wobble

When we pool the data regardless of the treatment, considering only the moment of evaluation (average of all treatments), there were significant differences in the capacitation status, $\mathrm{PM}$ integrity (Figure 3 ) and more $(\mathrm{P}<0.05)$ minor defects were observed at PT $(14.9 \pm 5.4 \%)$ than at $0 \mathrm{~h}(9.1 \pm 6.1 \%)$. On the other hand, the major defects were similar at PT $(2.7 \pm 1.6 \%)$ and Oh $(3.9 \pm 6.8 \%)$. No significant differences were observed in spermatozoa defects over time (data not shown). When analyzing just intact cells, the PT and post-selection protocols values were greater $(\mathrm{P}<0.05)$ than any incubation interval.

\section{DISCUSSION}

In this study, different Percoll protocols were tested in order to determine whether changes in the technique could bring any damage to ram frozen-thawed sperm. MP techniques and traditional Percoll were compared and there were no significant differences among them for most variables. This lack of difference corroborates with Machado et al. (2009), in catlle. Moreover, these authors showed that MP gradients had no adversely effect on cleavage rate or could even increase the blastocyst formation. The only study performed in sheep, but using fresh semen, reported no difference between MP and the swim-up technique in the parameters (Pegoraro et al., 2013). All together, these data lead to the possibility of reducing the volume of the gradient used and centrifugation time can open perspectives for the use of new technical protocols, reducing costs and semen processing time.

In the present study, all MP techniques showed higher values of VCL in comparison with traditional Percoll (Table 1). In sheep, the literature is not unanimous about which motility and kinematics parameters can reliably predict sperm fertility. However, in previous study, the authors observed that VCL and VAP presented a high correlation with ovine sperm migration, inferring these parameters are related with fertility (Robayo et al., 2008). García-Álvarez et al. (2014) also determined that they may correspond to hyperactivated spermatozoa, an essential event to spermatozoa be able to fertilize the oocyte.

No significant difference was detected in sperm recovery rates among treatments, corroborating other studies that tested different technical protocols, mostly in cattle (Machado et al., 2009; Folchini et al., 2012; Guimarães et al., 2014). Even when applying the same force and centrifugation time of traditional Percoll in a MP gradient (IV), the sperm recovery rate was unchanged, indicating a worthy replacement of the traditional Percoll. These reductions are offset by the increased centrifugal force assigned to protocols (Machado et al., 2009). 

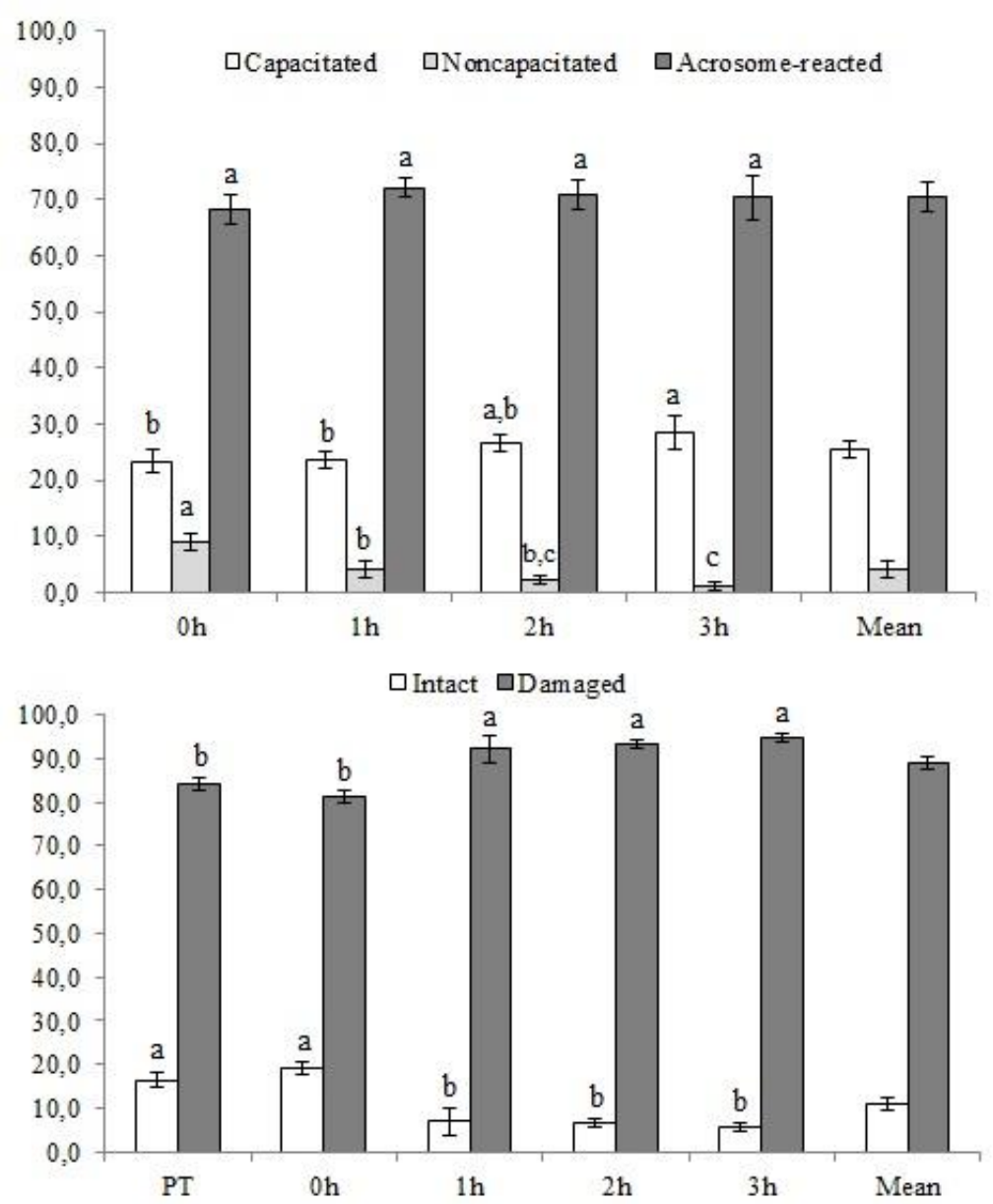

Figure 3. Capacitation status and plasma membrane (PM) integrity after different moments of Percoll protocols in ram frozen-thawed sperm of Santa Inês breed (Mean \pm SEM). Within a column, values without a common superscript (a,b,c) differ significantly by Tukey and Fisher-LSD tests $(\mathrm{P}<0.05) ; \mathrm{n}=50$ (ten replicates for each treatment). PT: Post thawing; 0h: immediately after treatments; $1 \mathrm{~h}, 2 \mathrm{~h}$ and $3 \mathrm{~h}$ : hours of incubation after each selection technique.

We observed a high rate of capacitated and acrosome-reacted cells at PT and after the protocols (0h; Figure 2), even considering the medium does not provide evidence to induce sperm capacitation in sheep. These high rates can be attributed to changes in sperm cell caused by the cryopreservation process. In a previous study, the authors reported that the passage of sperm by the particles of the Percoll gradient causes great destabilization of PM and facilitates the promotion of premature acrosome reaction in sheep (Cesari et al., 2006). It must be considered that the ovine sperm PM are probably more sensitive to destabilization when subjected to centrifugation (Gil et al., 1999). The current behavior of noncapacitated cells rate was similar to that reported by Gillan et al.(1997). The decrease noncapacitated in this rate was evident after $3 \mathrm{~h}$, due to the start of the capacitation event and, in turn coinciding with the increase of capacitated cells in the same interval. As the process of sheep sperm capacitation lasts around 2h (Austin, 1970), perhaps a longer incubation interval would be needed to ascertain the onset of acrosome reaction. This may explain why the acrosome-reacted cell rates have remained constant during incubation.

PT velocities values were higher than after the sperm selection protocols ( $0 \mathrm{~h}$; Table 2$)$. This may be due to the fact that mitochondria are damaged during the process of freezing and thawing, causing a reduction in the flagellar activity (Muiño et al., 2008) and, possibly, after 
the processing of sperm selection techniques. In addition to this fact, the decline of these parameters after the selection can be due to centrifugation process. The mechanical and oxidative stress of the centrifugation induce lipid peroxidation causing considerable damage to sperm functions, including, motility (Mortimer, 1991). A study in sheep have shown that even after the sperm selection, the cellular chromatin integrity, PM integrity and DNA fragmentation may change (García-Álvarez et al., 2010).

Low values were found in intact PM sperm cells rate, similar to a previous study (Folchini et al., 2012) in cattle. It is known that the process of freezing and thawing affects much less cell motility as compared with the damages of the PM integrity (Gil et al., 1999). Conversely, increasing the centrifugation force did not reduce the quality and integrity of ovine sperm PM on the results obtained in this study. Guimarães et al. (2014) observed that the $9000 \times \mathrm{x}$ centrifugation of MP, did not differ with respect to functional PM and morphology, still higher in the recovery of motile cells in relation to the protocols using lower forces. The similarity of the intact PM values in PT and after the treatments obtained in our study suggest the particles of the gradient are not harmful to ram sperm.

There is great evidence that Percoll gradients reduce the recovery of cells with morphological changes (Folchini et al., 2012; Guimarães et al., 2014). The reduction in the recovery of sperm presenting any pathologies appears as a further advantage of Percoll protocols, which in turn not only prevented damage to the sperm cells, but also improved the quality of the samples.

The present results indicated that the $80 \%$ reduction in the gradient volume and $33 \%$ in the time of centrifugation when increasing its force at Percoll density gradient technique, may be successfully used for ram frozen-thawed sperm.

\section{ACKNOWLEDGMENTS}

This research received a grant from Finep and Faperj (E-26/111.694/2013). JFF, CCSO and FZB are CNPq fellows and JMGSF was supported by CAPES.

\section{REFERENCES}

AUSTIN, C.R. Ageing and reproduction: postovulatory deterioration of the egg. J. Reprod. Fertil., v.12, p.39-53, 1970.

BLOOM, E. Ultrastructure of some characteristic sperm defects and a proposal for a new classification of the bull spermiogram. Nord. Vet. Med., v.25, p.383-391, 1973.

CESARI, A.; KAISER, G.G.; MUCCI, N. Integrated morphophysiological assessment of two methods for sperm selection in bovine embryos production in vitro. Theriogenology, v.66, 1185-1193, 2006.

CHAMBERLAND, A.; FOURNIER, I.V.; TARDFF, S. et al. The effect of heparin on motility parameters and protein phosphorylation during bovine sperm capacitation. Theriogenology, v.55, p.823-835, 2001.

COCERO, M.J.; ALABART, J.L.; HAMMAMI, S. et al. The efficiency of in vitro ovine embryo production using an undefined or a defined maturation medium is determined by the source of the oocyte. Reprod. Dom. Anim., v.46, v.463470, 2011.

CORMIER, N.; SIRARD, M.A; BAILEY, J.L. Premature capacitation of bovine spermatozoa is initiated by cryopreservation. J. Androl., v.18, p.461-468, 1997.

FOLCHINI, N.; LEIVAS, F.; SANTOS, F. Uso de mini-Percoll modificado para seleção e redução da formação de espécies reativas de oxigênio (ROS) em espermatozoides bovinos. Rev. Bras. Reprod. Anim., v.36, p.239-244, 2012.

GARCÍA-ÁLVAREZ, O.; MAROTOMORALES, A.; JIMÉNEZ-RABADÁN, P. et al. Effect of different media additives on capacitation of frozen-thawed ram spermatozoa as a potential replacement for estrous sheep serum. Theriogenology, v.84, p.948-955, 2015.

GARCÍA-ÁLVAREZ, O.; MAROTOMORALES, A.; RAMÓN, M. et al. Analysis of selected sperm by density gradient centrifugation might aid in the estimation of in vivo fertility of thawed ram spermatozoa. Theriogenology, v.74, p.979-988, 2010. 
GARCÍA-ÁLVAREZ, O.; MAROTO-MORALES, A.; RAMÓN, M. et al. Dynamics of sperm subpopulations based on motility and plasma membrane status in thawed ram spermatozoa incubated under conditions that support in vitro capacitation and fertilization. Reprod. Fertil. Devel., v.26, p.725-732, 2014.

GIL， J.; SÖDERQUIST, L.; RODRIGUEZMARTINEZ, H. Influence of centrifugation and different extenders on post-thaw sperm quality of ram semen. Theriogenology, v.54, p.93-108, 1999.

GILLAN, L.; EVANS, A.G.; MAXWELL, W.M.C. Capacitation status and fertility of fresh and frozen-thawed ram spermatozoa. Reprod. Fertil. Devel. v.9, p.481-487, 1997.

GUIMARÃES, A.C.G.; LEIVAS, F.G.; SANTOS, F.W. et al. Reduction of centrifugation force in discontinuous percoll gradients increases in vitro fertilization rates without reducing bovine sperm recovery. Anim. Reprod. Sci., v.146, p.103-110, 2014.

LUNA, C.; COLÁS, C.; CASAO, A. et al. Ram seminal plasma proteins contribute to sperm capacitation and modulate sperm-zona pellucida interaction. Theriogenology, v.83, p.670-678, 2015.

MACHADO, G.M.; CARVALHO, J.O.; FILHO, E.S. et al. Effect of Percoll volume, duration and force of centrifugation, on in vitro production and sex ratio of bovine embryos. Theriogenology, v.71, p.1289-1297, 2009.

MARA, L.; SANNA, D.; CASU, S. et al. Blastocyst rate of in vitro embryo production in sheep is affected by season. Zygote, v.22, p.366$371,2013$.

MORTIMER, D. Sperm preparation techniques and iatrogenic failures of in-vitro fertilization. Hum. Reprod., v.6, p.173-176, 1991.

MUIÑO, R.; RIVERA, M.M.; RIGAU, T. et al. Effect of different thawing rates on post-thaw sperm viability, kinematic parameters and motile sperm subpopulations structure of bull semen.Anim. Reprod. Sci., v.109, p.50-64, 2008.
OLIVARES, C.C.S.; FONSECA, J.F.; CAMARGO, L.S.A, et al. Comparison of different methods of goat sperm selection and capacitation for optimization of assisted reproductive technologies. Small Ruminant. Res., v.127, p.44-49, 2015.

PAPADOPOULOS, S.; HANRAHAN, J.P.; DONOVAN, A. et al. In vitro fertilization as a predictor of fertility from cervical insemination of sheep. Theriogenology, v.63, p.150-159, 2005.

PEGORARO, L.M.C.; SILVA, J.F.; CURTINAZ, A. et al. Different sperm selection methods used for ovine in vitro embryo production. In: ANNUAL MEETING OF THE BRAZILIAN EMBRYO TECHNOLOGY SOCIETY, 27., 2013, Gramado. Proceedings..., Gramado: SBTE, 2013. (Abstract).

PÉREZ-PÉ, R.; GRASA, P.; FERNÁNDEZJUAN, M. et al. Seminal plasma proteins reduce protein tyrosine phosphorylation in the plasma membrane of cold-shocked ram spermatozoa.Mol. Reprod. Devel., v.61, p.226233, 2002.

ROBAYO, I.; MONTENEGRO, V.; VALDÉS, C. et al. CASA Assessment of kinematic parameters of ram spermatozoa and their relationship to migration efficiency in ruminant cervical mucus. Reprod. Dom. Anim., v.43, p.393-399, 2008.

SHIRAZI, A; MOTAGHI, E. The in vitro fertilization of ovine oocytes in the presence of oviductal cells and its effect on the expression of zygote arrest 1 (zar1) and subsequent embryonic development. J. Reprod. Infertil., v.14, p.8-16, 2013.

SOUZA-FABJAN, J.M.G.; PANNEAU, B.; DUFFARD, N. et al. In vitro production of small ruminant embryos: late improvements and further research. Theriogenology, v.81, p.1149$62,2014$.

STREHLER, E.; BACCETTI, B.; STERZIK, K. Detrimental effects of polyvinylpyrrolidone on the ultrastructure of spermatozoa. Hum. Reprod., v.13, p.120-123, 1998.

WANG, Z.; LIN, P.; YU, S. Effects of ghrelin on developmental competence and gene expression of in vitro fertilized ovine embryos. Theriogenology, v.79, p.695-701, 2013. 